\title{
Analysis of Employee's Work Accident Trend for Policy Making to BPJS Ketenagakerjaan Participant in Medan Belawan Branch
}

\author{
Adriani Sinaga \\ Departmentof Management \\ University of Sumatera Utara \\ Medan, Indonesia \\ adriani.ardella@gmail.com
}

\author{
Yeni Absah \\ Department of Management \\ niversitas Sumatera Utara \\ Medan, Indonesia
}

\author{
Prihatin Lumbanraja \\ Department of Management \\ Universitas Sumatera Utara \\ Medan, Indonesia
}

\begin{abstract}
BPJS Ketenagakerjaan Branch Office Medan Belawan is a branch office that pays the highest occupational injury claim because it is in the area of Medan Industrial Estate. This study aims to analyze employee's work accident trend for policy making to BPJS Ketenagakerjaan participant in Medan Belawan branch. This research uses descriptive qualitative research method. Population and sample in this research are all the data accidents in the company that claimed to BPJS Ketenagakerjaan Medan Belawan branch from 2012 to 2016 the unit of analysis is 12,925 accident cases. The data will be analyzed to see the accidents trends using SPSS Program and Excel. The result of the research showsthattrend analysis of work accident in 2012-2016 is mostly happen to male employees in the age group 26-30 years old and take place in the work area at work hours 06.01-12.00. The accidents occur in the legs of workers that sourced from machinery (press, drill, saws, etc.) caused by using equipment in medium risk work. Trend prediction analysis of 2017-2021 is work accidents mostly happen to male employees, in the age group less than 25 years old; take place in the work area at work hours 06.01-12.00, many accidents occur in the fingers, sourced from environmental factors caused by using equipment in medium risk work.
\end{abstract}

Keywords - Trend, Prediction, Policy, Work Accident

\section{INTRODUCTION}

BPJS Ketenagakerjaan is social security that protects for workers to address certain socioeconomic risks and their implementation using social insurance mechanisms[1]. BPJS Ketenagakerjaan BPJS Employment is a state agency engaged in social insurance, previously named PT. Jamsostek (Persero) and a social executive security laws.

A high degree of health and safety in the workplace is a worker's right that companies must comply with in addition to other normative rights. Companies should be aware and understand that worker are not a resource that is constantly being exploited but as social beings that must be maintained and cared for given the many factors and risks that exist in the workplace. The government is also responsible for protecting health and safety.

Based on data from the International Labor Organization (ILO) in 2013, one worker in the world dies every 15 seconds due to workplace accidents or occupational diseases[2]. The ILO also noted that 153 worker in the world suffered work accidents every 15 seconds and estimated 2.3 million workers die each year from accidents and occupational diseases (PAK).

Every job always contains a potential risk of danger in the form of a work accident. A number of potential work related accidents and diseases depend on the type of production, the technology used, materials used, spatial and building environments and quality management and personnel executive.

The highest number of accident cases in 2011-2014 in 2013 was 35,917 cases of work accidents $(2011=9.891$, Year $2012=21,735$, Year $2014=24,910)$. The provinces with the highest number of accidents in 2011 were Banten, Central Java and East Java. In 2012 was Jambi, Maluku and Central Sulawesi. In 2013 were Aceh, North Sulawesi and Jambi. In 2014 was South Sulawesi, Riau and Bali. From these data can be seen the number of work accidents in Indonesia is still high.

BPJS Ketenagakerjaan Medan Belawan has some active labors which from year to year has increased significantly. The number of active workers in 2012 amounted to 39,244 , in 2013 as many as 49,366 workers, in 2014 as many as 61,567 workers, in 2015 as many as 88,741 and in 2016 was92.279.

Accidents that occur in the work environment result in losses for companies and labor. The perceived direct losses are medical expenses and compensation. Usually, if a worker has an accident, the company must still give monthly salary to the person who has an accident, and the company must also issue an overtime for replacing labor. Material losses such as medical expenses that are badly needed by the workforce for the restoration of health conditions. Losses to the workforce that is in accidental conditions that result in cure only with scars or torn scars, workers who experience fractures can use the pen in his body for several years, labor may even lose limbs with similar anatomical defects, permanent disability and total defective function.

The company must pay medical expenses and accident benefits in accordance with applicable regulations in the event of an accident[3]. BPJS Ketenagakerjaan of Medan Belawan Branch Office during 2012 until 2016, has paid medical and care expenses were amounting to Rp 19.7 billion, compensation of disability incentives amounting to $\mathrm{Rp} 8.3$ 
billion, Non-Working Benefit is employee salary during not working for Rp 4.7 billion, and death benefit amounting to $\mathrm{Rp}$ 19.7 billion. So the total losses due to work accidents that have been from 12,925 cases of $\mathrm{Rp} 52.5$ billion. Where the average unit cost and unit cost of compensation are 4.06 million per employee.

Due to work accidents, the company will also experience indirect losses, namely damage to production facilities. The company must pay for the damage. Many companies lulled by the assurance of the asset. But in reality, insurance will not pay all the losses, because there are things that are not included, such as loss of production, loss of market opportunities or customers. Therefore, even if an asset is insured, it does not mean that its security efforts are no longer required.

A Man-hour is the amount of work done by the average worker in an hour. A Man-hour is used in estimating the total amount of labor without experiencing any disruption in performing a task. The company suffered a loss of working hours, because the case of work accidents the production activities will surely stop for a while. The Company will conduct news events, damage or incident investigation. The loss of working hours lost due to accidents is large enough that can affect productivity. Accidents also bring harm to the production process due to damage or injury to employees. The company cannot temporarily take time to lose the opportunity to make a profit.

Pre-research conducted by interviews with companies, workers who have work accidents, external parties of Labor Supervisory Office of Social Workers, clinics or hospitals that perform treatment, to know what trends are causing work accidents. The cause of accidents can be caused by human factors, where employees sometimes do not always use personal protective equipment (PPE), lack of training in Occupational Safety and Health (K3), low education, and the work period is still a little so have no experience environment work. Other factors such as environmental factors, sometimes environmental noise so that employees are less to hear the direction of colleagues, uncomfortable air temperature, inadequate lighting and slippery floor surfaces often make employees slip. Equipment factors such as machines that are suddenly damaged due to lack of maintenance, can also cause work accidents.

This study aims to determine and analyze employee employment accidents BPJS Ketenagakerjaan Medan Belawan based on gender, age of workers, location of events, incidents, injuries, sources of injuries, malicious acts, the type of work and to predict and analyze employee employment accident Employment BPJS Ketenagakerjaan Medan Belawan for the next five years, from 2017 to 2021 .

\section{LITERATURE REVIEW}

The safety and health occupational is a thought and effort to guarantee the integrity and perfection of both physical and spiritual labor in particular and people in general, their work and culture towards a just and prosperous society[4].
Goverment Regulation of the Republic of Indonesia number 50 of 2012 on the Implementation of Occupational Safety and Health Management System, states that the Occupational Safety and Health Management System hereinafter abbreviated as SMK3 is part of the whole enterprise management system in the framework of risk control related to work activities in order to create workplace safe, efficient and productive [5].

Workers' social security is a guarantee of protection for workers suffering from accidents due to work, age, death and health care. With the issuance of Law No.3 / 1992 on social labor Guarantee, social security protection for labor becomes clearer because it has a legal basis that is Work Accident Guarantee (JKK), JHT, Death Insurance (JK) and Retirement Guarantee (JP).

The Work Accident Guarantee Program (JKK) is a program that protects against accidents occurring in employment relationships, including accidents occurring on the way from home to work or vice versa and diseases caused by the work environment [6].

\section{RESEARCH METHOD}

This research is descriptive research with a qualitative approach, conducted at BPJS Ketenagakerjaan Medan Belawan in J1. Gunung Krakatau Pelni Building No. 17A 2nd and 3rd floor of Medan in April 2017 to June 2017. Population in this research is all data of accidents at the company that filed a claim to BPJS Ketenagakerjaan Medan Belawan from 2012 until 2016. As for the population is 12,925 cases of accidents. In this study, no sampling and in other words, this study is capped, meaning that all data BPJS KetenagakerjaanBelawanBelawan within the period of 2012 to 2016 serve as an analysis unit that is as many as 12,925 cases of work accidents. Data collection techniques are interviews, observations and library studies. Data types is secondary data and primary data.

\section{RESULT}

Accidents trend on employees of BPJS KetenagakerjaanMedanBelawan in 2012-2016 are as follows:Based on gender, the trend of the number of accidents that most occurred in employees of the male is as many as 11043 accidents. Based on the age of the worker, the most common occupational accident rate for employees aged 26-30 years was 2,581 accidents. Based on the location of the incident, the most frequent occupational accidents in employees working in the work area were as many as 9080 accidents. Based on these incidents, the most frequent accidents occur in employees who work in the work. at 06.0112.00 the accident occurred as much as 5539. Based on the injured part of the body, the highest number of occupational accidents in the employee's foot is 2,568 accidents. Based on the source of injuries, the most common occupational accident rates came from machines (press, drill, saws, etc.) of 5510 accidents. Based on dangerous action, the trends of the number of most work accidents that occur in employees caused by the use of equipment is 6001 accidents. Based on the risks of occupation, most commonly the rate of occupational accidents 
occurring in employees with moderate employment risk was 9126 accidents.

The prediction of accidents trends in employees of BPJS Ketenagakerjaan partnership Medan Belawan in 20172021 are as follows, based on gender, the trend of the number of accidents that the most occurred in employees of the male is as many as 8475 accidents. Based on the age of the worker, the most common occupational accident rate occurring in $\leq 25$ years old employees was 3770 accidents. Based on the location of the incident, the most frequent occupational accident rate for employees who work in the work area is 7030 accidents. Based on these incidents, the most common occupational accident rate occurred in employees who worked during working hours of 06.01-12.00 ie 4585 accidents. Based on the injured part of the body, the highest number of work accident accidents on the fingers of employees' hands is 2585 accidents. Based on the source of injuries, the trend of the number of accidents in most of the work derived from environmental factors amounted to 2,455 accidents. Based on the dangerous action, the most common occupational accident rate that happened to the employees caused by the use of equipment that is as much as 4115 accidents. Based on the risk of occupation, the most common occupational accident rates occur in employees with moderate employment. the risk is $\mathbf{5 7 7 0}$ accidents.

\section{CONCLUSION}

The company should pay more attention to the conditions of each worker to minimize work accidents. For the young worker should be monitored and supervised by their superiors to avoid accidents. Active safety management is required so that work accidents can be minimized. Conducting periodic training of workers, especially training related to the use of work equipment and potential hazards present in the workplace. The company supervises to minimize the actions of unsafe workers. Establish hazard communication and safety promotion by creating posters and hazards in the workplace. Companies should provide standard APD at work and monitor the use of PPE to workers and strict sanctions for who do not use PPE when they work. Provide rewards who have reported unsafe actions and conditions at work. The government is the Ministry of Manpower should conduct an audit of the company against the implementation of existing safety management. Employee inspectors should keep an eye on cases of work accidents each year. The goverment through BPJS Ketenagakerjaan must continue to increase the compensation benefits to participating employees, continue to improve services to employees who have work accidents and carry out promotive and preventive activities to minimize accident cases. The student who will conduct research in the future, is expected to increase the number of respondents for interviews and observations for more good analysis.

\section{REFERENCES}

[1] Peraturan Menteri Ketenaga kerjaan Republik Indonesia Nomor 44 Tahun 2015 tentang Penyelenggaraan Program Jaminan Kecelakaan Kerja dan Jaminan Kematian Bagi Pekerja Harian Lepas, Borongan, dan Perjanjian Kerja Waktu Tertentu Pada Sektor Usaha jasa Konstruksi.

[2] Santoso,Gempur,Dr.,M.Kes. Manajemen Keselamatan dan Kesehatan Kerja. Jakarta, 2004.

[3] Benny, Pencegahan Kecelakaan Kerjapada Sektor Informal. Upaya Kesehatan Kerja Sektor Informal di Indonesia. Jakarta Indonesia 1991

[4] DepnakerRI, Tata Cara Pengajuan, Penilaian dan Pemberian Penghargaan Kecelakaan Nihil (ZeroAccidentAward). Jakarta, Indonesia, 2000.

[5] Peraturan Pemerintah Republik Indonesia No. 50 Tahun 2012 tentang Penerapan Sistem Manajemen Keselamatan dan Kesehatan Kerja

[6] Dalimunthe, M Erpandi, Analisis trend Kecelakaan Kerja Dari Tahun 2007 Sampai Dengan Tahun 2011 Berdasarkan Data PT. Jamsostek (Persero) Kantor Cabang Gatot Subroto I. Depok: Jakarta, 2012. 